Article

\title{
Experimental Study and Thermodynamic Analysis of Hydrogen Production through a Two-Step Chemical Regenerative Coal Gasification
}

\author{
Wei $\mathrm{Li}^{1}$, Song $\mathrm{He}^{2,3}$ and Sheng $\mathrm{Li}^{2, *}$ \\ 1 Ningbo Institute of Technology, Zhejiang University, Ningbo 315000, China \\ 2 Institute of Engineering Thermophysics, Chinese Academy of Sciences, Beijing 100190, China \\ 3 University of Chinese Academy of Sciences, Beijing 100190, China \\ * Correspondence: lisheng@iet.cn; Tel.: +86-10-8254-3163
}

Received: 12 July 2019; Accepted: 26 July 2019; Published: 27 July 2019

\begin{abstract}
Hydrogen, as a strategy clean fuel, is receiving more and more attention recently in China, in addition to the policy emphasis on $\mathrm{H}_{2}$. In this work, we conceive of a hydrogen production process based on a chemical regenerative coal gasification. Instead of using a lumped coal gasification as is traditional in the $\mathrm{H}_{2}$ production process, herein we used a two-step gasification process that included coking and char-steam gasification. The sensible heat of syngas accounted for $15-20 \%$ of the total energy of coal and was recovered and converted into chemical energy of syngas through thermochemical reactions. Moreover, the air separation unit was eliminated due to the adoption of steam as oxidant. As a result, the efficiency of coal to $\mathrm{H}_{2}$ was enhanced from $58.9 \%$ in traditional plant to $71.6 \%$ in the novel process. Further, the energy consumption decreased from $183.8 \mathrm{MJ} / \mathrm{kg}$ in the traditional plant to $151.2 \mathrm{MJ} / \mathrm{kg}$ in the novel process. The components of syngas, $\mathrm{H}_{2}$, and efficiency of gasification are herein investigated through experiments in fixed bed reactors. Thermodynamic performance is presented for both traditional and novel coal to hydrogen plants.
\end{abstract}

Keywords: hydrogen production; gasification; thermodynamic analysis; fixed bed reactor

\section{Introduction}

As a result of the new round of hydrogen energy economy flourish, hydrogen production from coal is receiving increased research focus. Hydrogen is vital to future energy systems. It is clean, carbon free, and an important material for chemical industries [1-3]. Moreover, $\mathrm{H}_{2}$ can be used to generate power, drive cars, and synthesize chemicals such as methanol and ethanol, but unfortunately cannot be gained from natural gas reservoirs $[4,5]$. Therefore, there is great significance in retrieving efficient hydrogen production from other sources. Compared with other hydrogen production options for China, coal to $\mathrm{H}_{2}$ has a strategic importance due to the country's large amount of coal reserves.

Coal to hydrogen technology is based on coal gasification, which originated early last century [6,7]. The process has been developed over the past 20 years in China in conjunction with several commercialized projects [8,9]. The basic process involves coal gasification, water gas shift (WGS), and gas separation. Coal gasification is the main unit that decides the whole plant efficiency. Currently, the majority of coal to hydrogen processes employ GE and Shell gasification, which uses oxygen as an oxidant. Further, the cold gas efficiencies are typically lower than $80 \%[10,11]$. Nevertheless, the low cold gas efficiency and use of oxygen limits coals hydrogen efficiency to less than $60 \%$ [12,13]. In recent years, several alternative coal gasification technologies have been proposed, including Huaneng TPRI (Thermal Power Research Institute) and transport integrated gasification (TRIG). These new technologies have a higher cold gas efficiency and are able to improve coal to hydrogen efficiency [14,15]. However, most of these 
technologies still need oxygen for gasification, a process which results in huge power consumption. Another coal to hydrogen process is based on supercritical water gasification [16-18]. This technology does not require pure oxygen and is expected to be highly efficient. Many previous experiments have been carried out to prove these findings [16-18]. For example, hydrogen mole fraction for this technology was reported to be higher than $70 \%$ [16-18]. Nevertheless, supercritical water coal gasification operates over $20 \mathrm{MPa}$ and may result in a higher cost for the gasifier. There are some publications relative to the topic of hydrogen production through steam gasification of coal, char, and biomass [19-23]. Herein, thermodynamic and kinetic analysis are presented.

In our previous paper [24], a two-step chemical regenerative coal gasification was proposed and a much higher cold gas efficiency was reported. Moreover, in the two-step gasification, gas with high $\mathrm{H}_{2}$ concentration was produced. In this paper, a coal to hydrogen process based on this gasification is presented. Experiments were carried out in fixed bed reactors and components of syngas, $\mathrm{H}_{2}$, are reported. Additionally, thermodynamic performance of the whole process is simulated.

\section{Hydrogen Production Based on a Two-Step Chemical Regenerative Coal Gasification}

In a traditional coal to hydrogen plant, GE or Shell gasification is typically employed. Figure 1a shows the most popular process based on GE gasification, wherein coal is mixed with water to produce slurry. The slurry reacts with oxygen from an air separation unit (ASU) to produce syngas containing $\mathrm{CO}$ and $\mathrm{H}_{2}$. Water is used to quench the syngas and then a waste heat boiler (WHB) is used to recover heat. Afterward, syngas is sent to a water gas shift (WGS) where sulfur removal and a pressure swing adsorption (PSA) unit are used to produce high purity $\mathrm{H}_{2}$. Limited by the low cold gas efficiency of gasification, it is typically lower than $80 \%[10,11]$. Considering a huge power consumption for ASU, the efficiency of coal to hydrogen in such a traditional plant is lower than $60 \%$ (LHV based) [12,13].

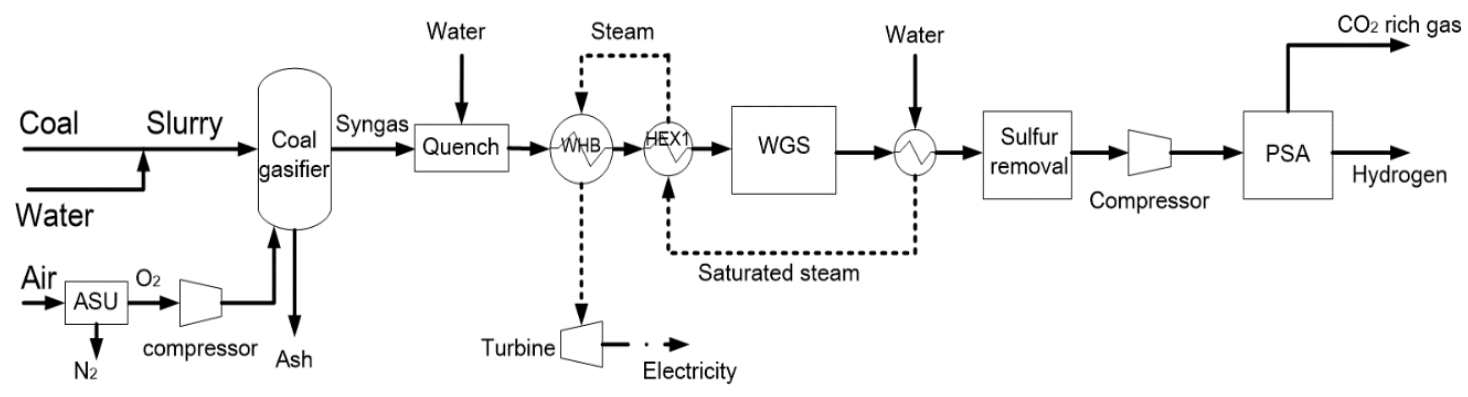

(a) Traditional hydrogen production process from coal

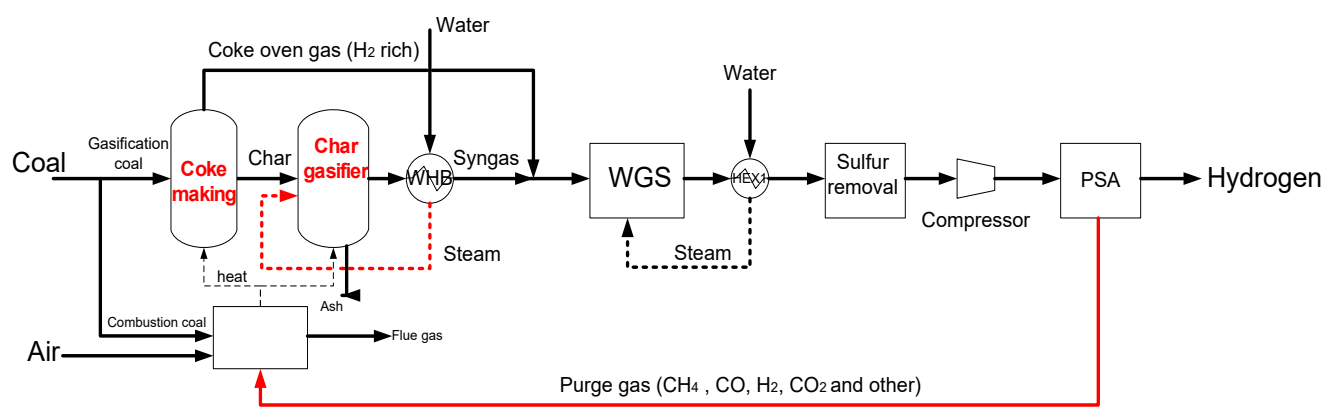

(b) Hydrogen production based on a two-step chemical regenerative coal gasification

Figure 1. (a) Traditional hydrogen production process from coal. (b) Proposed hydrogen production process based on a two-step chemical regenerative coal gasification.

In this novel process, a two-step chemical regenerative coal gasification is proposed for $\mathrm{H}_{2}$ production (Figure 1b). Coal gasification is divided into two steps: coke making and char gasification. The coke making process can drive volatile out of coal and can get char and high $\mathrm{H}_{2}$ concentration 
gas, i.e., coke oven gas (COG). For char-steam gasification, steam is used to recover syngas sensible heat, providing part of the heat requirement of the char-steam reaction. Through such a chemical regenerative pathway, the sensible heat of the syngas can be converted into the chemical energy of the syngas, wherein cold gas efficiency of gasification is expected to be lifted. To produce $\mathrm{H}_{2}$, COG and syngas will be sent to the WGS unit, sulfur unit, and PSA unit. Moreover, the purge gas from the PSA unit mainly contains $\mathrm{CH}_{4}, \mathrm{H}_{2}, \mathrm{CO}$, and $\mathrm{CO}_{2}$ and can be recovered to combust together with coal, which provides heat for coke making and char-steam gasification. Furthermore, no oxygen is needed for coal gasification and consequently ASU is eliminated.

\section{Experimental Setup and Results}

The gasification unit is the key unit for the proposed hydrogen production process. Several experiments have been carried out for validation.

\subsection{Experimental Setup}

In this study, the experiment equipment mainly includes char making, steam generation, char-steam gasification, and a gas analyzer. First, coal is dried in a burner at $101{ }^{\circ} \mathrm{C}$ for $12 \mathrm{~h}$ after being crushed into powder under $2 \mathrm{~mm}$. Then it is placed in a vacuum tube for char and coke oven gas (COG) production. The infrared-heated reaction tube has a maximum heating rate of $50^{\circ} \mathrm{C} / \mathrm{s}$ and can heat the coal to $1000{ }^{\circ} \mathrm{C}$ in $20 \mathrm{~s}$. COG gas is collected by bags after processing water washing, cooling, and filter. The prepared char will be placed in a fixed bed reactor to react with steam that is generated in a steam generator. Gas from char-steam reactor is detected through an online gas analyzer (GA) and collected by bags. Aglient 490 pro chromatogram is used to analyze the final components of all collected gases. The experiment setup is shown in Figure 2.

\subsection{Typical Results of Char Making}

Bituminous coal, the components of which are shown in Table 1, is used, wherein char is prepared at $900{ }^{\circ} \mathrm{C}$ at a heating rate $25^{\circ} \mathrm{C} / \mathrm{s}$. The components and production of COG and char are presented in Tables 2 and 3. It can be seen that through the coke making process, COG gas with high $\mathrm{H}_{2}$ concentration can be made.

Table 1. Components and lower heating value of coal sample.

\begin{tabular}{ccccccc}
\hline $\mathbf{C}$ & $\mathbf{H}$ & $\mathbf{O}$ & $\mathbf{N}$ & $\mathbf{S}$ & ASH & LHV, KJ/KG \\
\hline $74.3 \%$ & $4.7 \%$ & $10.7 \%$ & $0.87 \%$ & $0.33 \%$ & $9.1 \%$ & $26,835.8$ \\
\hline
\end{tabular}

Table 2. Components of coke oven gas (COG) production.

\begin{tabular}{cc}
\hline Component & COG \\
\hline $\mathbf{C O}$ & $21.9 \%$ \\
$\mathbf{H}_{2}$ & $51.7 \%$ \\
$\mathbf{O}_{2}$ & $1.7 \%$ \\
$\mathbf{N}_{2}$ & $9.0 \%$ \\
$\mathrm{CH}_{4}$ & $11.6 \%$ \\
$\mathbf{H}_{\mathbf{2}} \mathbf{O}$ & - \\
$\mathbf{H}_{2} \mathbf{S}$ & $0.1 \%$ \\
$\mathrm{CO}_{2}$ & $3.5 \%$ \\
$\mathbf{C}_{2} \mathbf{H}_{4}$ & $0.5 \%$ \\
Volume Per kg Coal & $563.85 \mathrm{~L}$ \\
\hline
\end{tabular}


Table 3. Components of char.

\begin{tabular}{cc}
\hline Component & Char \\
\hline C & $94.94 \%$ \\
H & $0.55 \%$ \\
O & $0.39 \%$ \\
N & - \\
S & - \\
Ash & $4.12 \%$ \\
Char Yield, kg Per kg Coal & $59.33 \%$ \\
\hline
\end{tabular}

\subsection{Typical Results of Char-Steam Gasification}

Next, $10 \mathrm{~g}$ char is placed in the reaction tube and $0.2 \mathrm{~g} / \mathrm{mL}$ steam is sent to gasify the char at $1000-1100{ }^{\circ} \mathrm{C}$. The char conversion ratio is $54.0 \%$ at $1000{ }^{\circ} \mathrm{C}$ after $1 \mathrm{~h}$. Online gas components of products at different temperatures are shown in Figures 3-5 (each experiment at different temperatures is repeated three times; the average values of gas components are used in the figures). $\mathrm{H}_{2}$ concentration is typically higher than $70 \%$ and the rest mainly includes $\mathrm{CO}$ and $\mathrm{CO}_{2}$. Besides carbon reaction with steam, it can be inferred from the gas fraction of carbon dioxide that the water gas shift reaction also occurred to further convert $\mathrm{CO}$ into $\mathrm{H}_{2}$ and $\mathrm{CO}_{2}$.

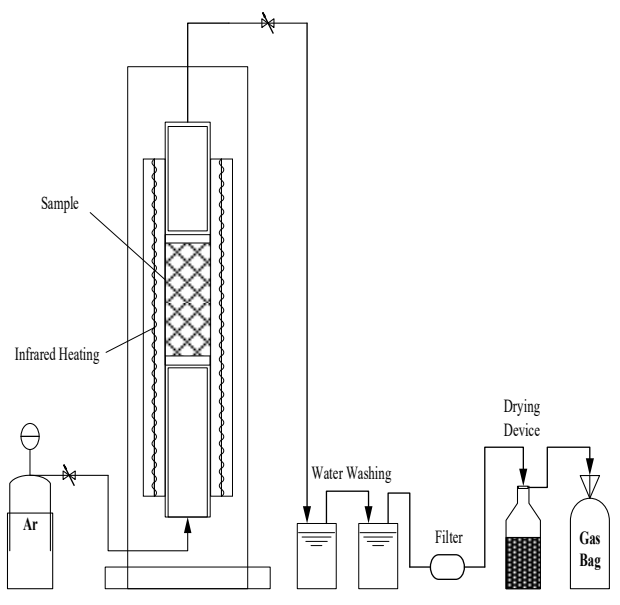

(a)

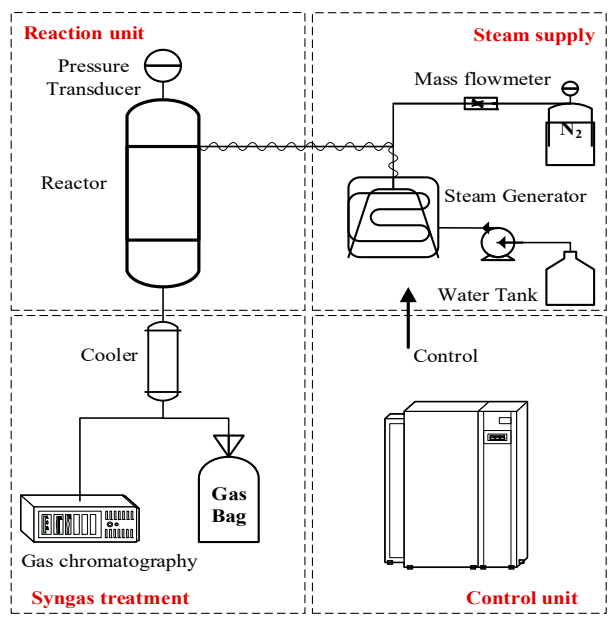

(b)

Figure 2. Experimental setup for (a) char making and (b) char-steam gasification [24].

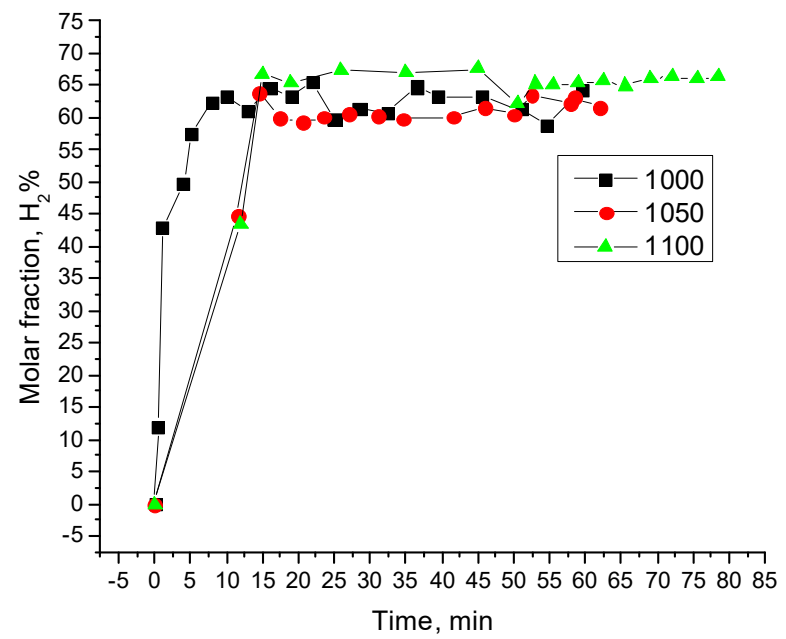

Figure 3. Online $\mathrm{H}_{2}$ fraction from char-steam gasification at different tempeatures. 


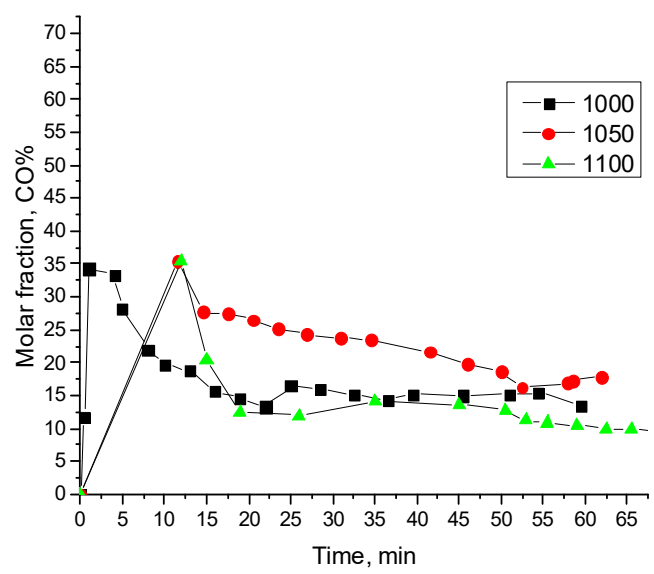

Figure 4. Online $\mathrm{CO}$ fraction from char-steam gasification at different tempeatures.

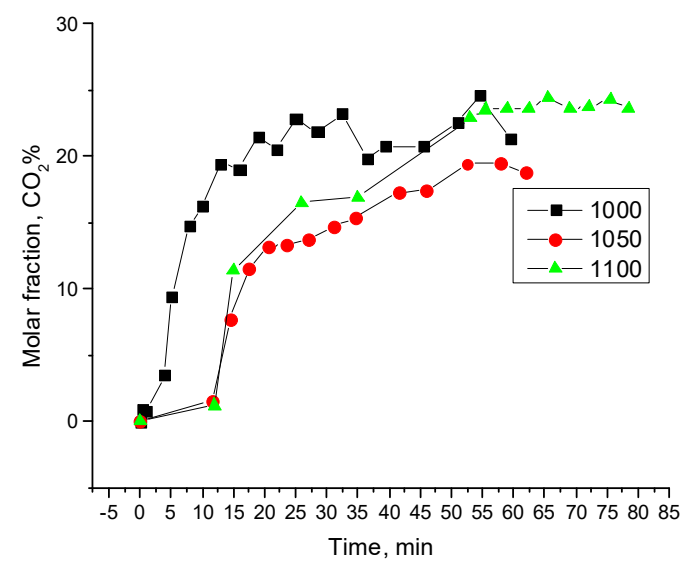

Figure 5. Online $\mathrm{CO}_{2}$ fraction from char-steam gasification at different tempeatures.

\section{Thermodynamic Performance Comparison and Discussion}

Based on the above experimental results, thermodynamic performance of the whole process is presented in this section. ASPEN PLUS software V8.2 was used for process simulation and the PR-BM method was selected. Next, $1300{ }^{\circ} \mathrm{C}$ and $4 \mathrm{MPa}$ was assumed for GE gasification; $1100{ }^{\circ} \mathrm{C}$ and 2.5 MPa was assumed for char-steam gasification. In the proposed process, part of the coal was sent to the combustion chamber to provide heat to coking and char-steam reaction. The temperature of combustion was $1150{ }^{\circ} \mathrm{C}$ and the temperature of flue gas was $120^{\circ} \mathrm{C}$. The PSA unit for both processes operated at $5 \mathrm{MPa}$ and the purity of the $\mathrm{H}_{2}$ product was $99.9 \%$. Three indicators were used to evaluate thermodynamic performance, as shown in Equations (1)-(3). Cold gas efficiency represented the ratio of converting chemical energy of coal into syngas. The coal to hydrogen efficiency denoted the amount of chemical energy of coal converted into hydrogen product. Exergy efficiency stood for the ratio of the exergy of $\mathrm{H}_{2}$ product to the exergy of feed coal.

Cold gas efficiency $=$ Lower heating value of syngas/Lower heating value of coal

Coal to hydrogen efficiency $=$ Lower heating value of hydrogen product/Lower heating value of coal (2)

$$
\text { Exergy efficiency }=\text { Exergy of hydrogen product/Exergy of coal }
$$

Experimental results of char making process were directly used for char-steam gasification simulation. Further, the simulated results of syngas components agreed well with the experiments presented in Figure 3. A thermodynamic analysis showed that coal to hydrogen efficiency based on chemical regenerative gasification was as high as $71.6 \%$ (LHV based), which was far higher than 
$58.9 \%$ of traditional GE gasification-based plant. Moreover, the energy consumption for unit hydrogen production decreased from $183.8 \mathrm{MJ} / \mathrm{kg}$ in a traditional plant to $151.2 \mathrm{MJ} / \mathrm{kg}$ in this novel process. The efficiency upgrade was mainly caused by the improvement of cold gas efficiency during coal gasification, in addition to being brought by the reduction of power consumption for air separation (Table 4). By recovering the sensible heat of syngas to drive gasification reaction, sensible heat was converted into the chemical energy of syngas and thereby the cold gas efficiency of chemical regenerative gasification was lifted by $5.6 \%$. Adopting steam instead of pure oxygen as an oxidant reduced the power consumption for air separation (Table 5). Thus, the coal input for the auxiliary power generation is reduced, which further helped improve the whole plant efficiency. To disclose the reason for system performance enhancement, exergy analysis is also presented in Table 6 . The exergy efficiency of the novel coal to hydrogen plant was $78.5 \%$, which was 13.9 percentage points higher than the traditional plant. It can be seen that the efficiency upgrade was mainly a result of the reduction in exergy destruction of coal gasification, air separation, auxiliary power generation, and heat recovery of syngas units. Eliminating the air separation unit reduced exergy destruction by 3.1 percentages and the coal gasification unit (including char making and char gasification) reduced exergy destruction by 4.3 percentages. Because there is no power consumption for air separation, the exergy destruction in auxiliary power generation unit also decreased by $2.3 \%$. Furthermore, recovery of syngas sensible heat instead of quenching reduced exergy destruction by $2.8 \%$.

Table 4. Thermodynamic performance of the hydrogen production plant.

\begin{tabular}{|c|c|c|c|c|}
\hline \multirow[t]{2}{*}{ Item } & \multicolumn{2}{|c|}{$\begin{array}{l}\text { Hydrogen Production Based on } \\
\text { Chemical Regenerative Gasification }\end{array}$} & \multicolumn{2}{|c|}{$\begin{array}{l}\text { Hydrogen Production Based } \\
\text { on GE Gasification }\end{array}$} \\
\hline & \multicolumn{4}{|c|}{ Total System Input } \\
\hline \multicolumn{5}{|l|}{ Energy Input, kJ } \\
\hline $\begin{array}{l}\text { Coal input for gasification (including } \\
\text { to gasifier and combustion unit) }\end{array}$ & $25,842.9$ & $96.3 \%$ & $24,071.7$ & $89.7 \%$ \\
\hline $\begin{array}{l}\text { Coal input for auxiliary power } \\
\text { generation }\end{array}$ & 992.9 & $3.7 \%$ & 2764.1 & $10.3 \%$ \\
\hline subtotal & $26,835.8$ & $100.0 \%$ & $26,835.8$ & $100.0 \%$ \\
\hline \multicolumn{5}{|c|}{ Gasification Island } \\
\hline \multicolumn{5}{|l|}{ Energy Input, kJ } \\
\hline Coal input for gasification & $25,842.9$ & - & $24,071.7$ & - \\
\hline LHV of purge gas recovered from PSA & 4588.9 & - & - & - \\
\hline Subtotal & $30,431.8$ & & $24,071.7$ & \\
\hline Gas output from gasifier and COG, $\mathrm{kJ}$ & $25,333.0$ & & $18,677.7$ & - \\
\hline Cold gas efficiency of gasification & & $83.2 \%$ & & $77.6 \%$ \\
\hline \multicolumn{5}{|c|}{ WGS and PSA Unit } \\
\hline \multicolumn{5}{|l|}{ Energy Output, kJ } \\
\hline Hydrogen & $19,214.4$ & & $15,806.3$ & \\
\hline LHV of purge gas & 4588.9 & & - & \\
\hline \multicolumn{5}{|c|}{ Coal to $\mathrm{H}_{2}$ Efficiency } \\
\hline Coal to $\mathrm{H}_{2}$ efficiency & & $71.6 \%$ & & $58.9 \%$ \\
\hline $\begin{array}{l}\text { Energy consumption for unit } \\
\text { hydrogen production, } \mathrm{MJ} / \mathrm{kg}\end{array}$ & & 151.2 & & 183.8 \\
\hline
\end{tabular}


Table 5. Power balance of the plant.

\begin{tabular}{ccc}
\hline Item & $\begin{array}{c}\text { Hydrogen Production Based on } \\
\text { Chemical Regenerative Gasification }\end{array}$ & $\begin{array}{c}\text { Hydrogen Production } \\
\text { Based on GE Gasification }\end{array}$ \\
\hline Power Produced, kJ & & \\
\hline $\begin{array}{c}\text { Power from auxiliary power } \\
\text { generation }\end{array}$ & 397.2 & 1105.6 \\
\hline Power from heat recovered & - & 358.4 \\
\hline subtotal & 397.2 & 1464.0 \\
\hline Power Consumption in Each Unit, kJ & & 898.2 \\
\hline ASU & - & 434.8 \\
Oxygen compression & - & 131.0 \\
PSA & 397.2 & 1464.0 \\
\hline Subtotal & 397.2 & \\
\hline
\end{tabular}

Table 6. Exergy balance of the hydrogen production plant.

\begin{tabular}{|c|c|c|c|c|}
\hline Item & \multicolumn{2}{|c|}{$\begin{array}{c}\text { Hydrogen Production Based on } \\
\text { Chemical Regenerative Gasification }\end{array}$} & \multicolumn{2}{|c|}{$\begin{array}{l}\text { Hydrogen Production Based } \\
\text { on GE Gasification }\end{array}$} \\
\hline \multicolumn{5}{|c|}{ Total System Input } \\
\hline \multicolumn{5}{|l|}{ Exergy Input, kJ } \\
\hline $\begin{array}{l}\text { Coal input for gasification (including to } \\
\text { gasifier and combustion unit) }\end{array}$ & $26,876.6$ & $96.3 \%$ & $25,034.6$ & $89.7 \%$ \\
\hline Coal input for auxiliary power generation & 1032.6 & $3.7 \%$ & 2874.6 & $10.3 \%$ \\
\hline subtotal & $27,909.2$ & $100.0 \%$ & $27,909.2$ & $100.0 \%$ \\
\hline \multicolumn{5}{|c|}{ Exergy Destruction } \\
\hline Air separation and oxygen compression & - & - & 865.2 & $3.1 \%$ \\
\hline $\begin{array}{l}\text { Coal gasification (including char making } \\
\text { and char gasification) }\end{array}$ & 3070.0 & $11.0 \%$ & 4270.1 & $15.3 \%$ \\
\hline Quench or heat recovery of syngas & 753.5 & $2.7 \%$ & 1535.0 & $5.5 \%$ \\
\hline WGS & 669.8 & $2.4 \%$ & 641.9 & $2.3 \%$ \\
\hline Shifted gas cooling & 195.4 & $0.7 \%$ & 725.6 & $2.6 \%$ \\
\hline PSA unit & 697.7 & $2.5 \%$ & 614.0 & $2.2 \%$ \\
\hline Auxiliary power generation & 614.0 & $2.2 \%$ & 1255.9 & $4.5 \%$ \\
\hline Subtotal & 6000.5 & $21.5 \%$ & 9879.9 & $35.4 \%$ \\
\hline \multicolumn{5}{|c|}{ Exergy Output } \\
\hline \multicolumn{5}{|l|}{ Exergy Output, kJ } \\
\hline Hydrogen & $21,908.7$ & $78.5 \%$ & $18,029.3$ & $64.6 \%$ \\
\hline \multicolumn{5}{|c|}{ Exergy Efficiency of Coal to $\mathrm{H}_{2}$} \\
\hline Exergy efficiency of coal to $\mathrm{H}_{2}$ & & $78.5 \%$ & & $64.6 \%$ \\
\hline
\end{tabular}

\section{Conclusions}

In this study, a hydrogen production process based on a chemical regenerative coal gasification was conceived. A two-step gasification process that employed coking and char-steam gasification was adopted instead of a lumped coal gasification, as is commonly done in the traditional $\mathrm{H}_{2}$ production process. Experimental results shows that by the adoption of two-step gasification, COG gas with high $\mathrm{H}_{2}$ purity and syngas with $\mathrm{H}_{2}$ over $70 \%$ were both produced. The efficiency of coal to $\mathrm{H}_{2}$ can be enhanced from $58.9 \%$ in the traditional plant to $71.6 \%$ in the novel process. The lifting of coal to hydrogen efficiency were mainly accomplished using the cold gas efficiency improvement due to recovering and converting the sensible heat of syngas into the chemical energy of syngas through 
thermochemical reactions. Further, the reduction of auxiliary power consumption was caused by the elimination of the air separation unit.

Author Contributions: Methodology, S.L.; validation, W.L., S.H.; writing—original draft preparation, S.L., W.L.; writing-review and editing, S.L.; supervision, S.L.

Funding: This research was funded by the National Key R\&D Program of China (No. 2016YFB0600803), the National Nature Science Foundation of China (No. 51776197) and the Youth Innovation Promotion Association CAS (2016130).

Conflicts of Interest: The authors declare no conflict of interest.

\section{References}

1. Vaiano, V.; Iervolino, G. Photocatalytic Hydrogen Production from Glycerol Aqueous Solution Using Cu-Doped $\mathrm{ZnO}$ under Visible Light Irradiation. Appl. Sci. 2019, 9, 2741. [CrossRef]

2. Dincer, I.; Acar, C. Review and evaluation of hydrogen production methods for better sustainability. Int. J. Hydrogen Energy 2015, 40, 11094-11111. [CrossRef]

3. Herdem, M.S.; Farhad, S.; Dincer, I.; Hamdullahpur, F. Thermodynamic modeling and assessment of a combined coal gasification and alkaline water electrolysis system for hydrogen production. Int. J. Hydrogen Energy 2014, 39, 3061-3071. [CrossRef]

4. Jin, H.; Chen, Y.; Ge, Z.; Liu, S.; Ren, C.; Guo, L. Hydrogen production by Zhundong coal gasification in supercritical water. Int. J. Hydrogen Energy 2015, 40, 16096-16103. [CrossRef]

5. Hosseini, S.E.; Wahid, M.A. Hydrogen production from renewable and sustainable energy resources: Promising green energy carrier for clean development. Renew. Sustain. Energy Rev. 2016, 57, 850-866. [CrossRef]

6. Irfan, M.F.; Usman, M.R.; Kusakabe, K. Coal gasification in $\mathrm{CO}_{2}$ atmosphere and its kinetics since 1948: A brief review. Energy 2011, 36, 12-40. [CrossRef]

7. Nicoletti, G. The hydrogen option for energy: A review of technical, environmental and economic aspects. Int. J. Hydrogen Energy 1995, 20, 759-765. [CrossRef]

8. Acar, C.; Dincer, I. Comparative assessment of hydrogen production methods from renewable and non-renewable sources. Int. J. Hydrogen Energy 2014, 39, 1-12. [CrossRef]

9. Parthasarathy, P.; Narayanan, K.S. Hydrogen production from steam gasification of biomass: Influence of process parameters on hydrogen yield-A review. Renew. Energy 2014, 66, 570-579. [CrossRef]

10. Chen, J.; Chen, W.; Jiao, Y.; Wang, X. Gasification Kinetics of Bituminous Coal Char in the Mixture of $\mathrm{CO}_{2}$, $\mathrm{H}_{2} \mathrm{O}, \mathrm{CO}$, and $\mathrm{H}_{2}$. Energies 2019, 12, 496. [CrossRef]

11. Prins, M.J.; Ptasinski, K.J.; Janssen, F.J. From coal to biomass gasification: Comparison of thermodynamic efficiency. Energy 2007, 32, 1248-1259. [CrossRef]

12. Seyitoglu, S.S.; Dincer, I.; Kilicarslan, A. Energy and exergy analyses of hydrogen production by coal gasification. Int. J. Hydrogen Energy 2017, 42, 2592-2600. [CrossRef]

13. Bargigli, S.; Raugei, M.; Ulgiati, S. Comparison of thermodynamic and environmental indexes of natural gas, syngas and hydrogen production processes. Energy 2004, 29, 2145-2159. [CrossRef]

14. Zhuang, Q.; Biondi, M.; Yan, S.; Bhagat, K.; Vansickle, R.; Chen, C.; Tan, H.; Zhu, Y.; You, W.; Xia, W. TRIG ${ }^{\mathrm{TM}}$ : An advanced gasification technology to utilize low rank coals for power. Fuel 2015, 152, 103-109. [CrossRef]

15. Wang, B.; Li, X.; Xu, S.; Paterson, N.; Dugwell, D.R.; Kandiyoti, R. Performance of Chinese Coals under Conditions Simulating Entrained-Flow Gasification. Energy Fuels 2005, 195, 2006-2013. [CrossRef]

16. Jin, H.; Lu, Y.; Liao, B.; Guo, L.; Zhang, X. Hydrogen production by coal gasification in supercritical water with a fluidized bed reactor. Int. J. Hydrogen Energy 2010, 35, 7151-7160. [CrossRef]

17. Li, Y.; Guo, L.; Zhang, X.; Jin, H.; Lu, Y. Hydrogen production from coal gasification in supercritical water with a continuous flowing system. Int. J. Hydrogen Energy 2010, 35, 3036-3045. [CrossRef]

18. Guo, L.; Jin, H. Boiling coal in water: Hydrogen production and power generation system with zero net $\mathrm{CO}_{2}$ emission based on coal and supercritical water gasification. Int. J. Hydrogen Energy 2013, 38, 12953-12967. [CrossRef] 
19. Yilmaz, F.; Ozturk, M.; Selbas, R. Design and thermodynamic analysis of coal-gasification assisted multigeneration system with hydrogen production and liquefaction. Energy Convers. Manag. 2019, 186, 229-240. [CrossRef]

20. Bai, L.; Kudo, S.; Norinaga, K.; Wang, Y.G.; Hayashi, J.I. Kinetics and Mechanism of Steam Gasification of Char from Hydrothermally Treated Woody Biomass. Energy Fuels 2014, 28, 7133-7139. [CrossRef]

21. Huang, Y.; Wang, Y.; Zhou, H.; Gao, Y.; Xu, D.; Bai, L.; Zhang, S. Effects of Water Content and Particle Size on Yield and Reactivity of Lignite Chars Derived from Pyrolysis and Gasification. Molecules 2018, 23, 2717. [CrossRef] [PubMed]

22. Tian, B.; Qiao, Y.; Bai, L.; Liu, F.; Tian, Y.; Xie, K. Separation and structural characterization of groups from a high-volatile bituminous coal based on multiple techniques. Fuel Process. Technol. 2017, 159, 386-395. [CrossRef]

23. Tian, B.; Qiao, Y.; Fan, J.; Bai, L.; Tian, Y. Coupling Pyrolysis and Gasification Processes for Methane-Rich Syngas Production: Fundamental Studies on Pyrolysis Behavior and Kinetics of a Calcium-Rich High-Volatile Bituminous Coal. Energy Fuels 2017, 31, 10665-10673. [CrossRef]

24. Wang, D.; Li, S.; He, S.; Gao, L. Coal to substitute natural gas based on combined coal-steam gasification and one-step methanation. Appl. Energy 2019, 240, 851-859. [CrossRef]

(C) 2019 by the authors. Licensee MDPI, Basel, Switzerland. This article is an open access article distributed under the terms and conditions of the Creative Commons Attribution (CC BY) license (http://creativecommons.org/licenses/by/4.0/). 